\title{
An Ottoman Cargo Ship Drawing from Russian Archives
}

\section{Rus Arşivlerinde Bulunan Bir Osmanlı Gemisi Çizimi}

\author{
Evren Türkmenoğlu ${ }^{1}$ (C)
}

'Dr. Öğr. Üyesi, İstanbul Üniversitesi, Edebiyat Fakültesi, Kültür Varlıkları ve Onarımı Bölümü, Istanbul, Türkiye

\section{ORCID: E.T. 0000-0002-5869-7360}

\section{Corresponding author/Sorumlu yazar:} Evren Türkmenoğlu,

Istanbul Üniversitesi Edebiyat Fakültesi Kültür Varıkları ve Onarımı Bölümü

Istanbul, Türkiye

E-mail/E-posta: evrenturkmenoglu@gmail.com

\section{Submitted/Başvuru: 31.05 .2021}

Revision Requested/Revizyon Talebi:

03.10.2021

Last Revision Received/Son Revizyon:

17.10.2021

Accepted/Kabul: 21.10.2021

Citation/Atıf: Evren Türkmenoğlu, "An Ottoman Cargo Ship Drawing from Russian Archives." Osmanlı Bilimi Araştırmaları 23, 1 (2022): 127-135. https://doi.org/10.26650/oba.946086

\begin{abstract}
Although the types of the Ottoman ships in the age of sail are well known to historians, sources on their technical characteristics are notably limited when compared to their counterparts in western Europe. While Ottoman archives usually offer rich inventory accounts, harbor logs and fiscal records, direct technical evidence such as plans, sketches or hull lines drawings are scarce. A recent research of Russian archives has provided new evidence of $18^{\text {th }}$ and $19^{\text {th }}$ century Ottoman ships. This study presents a multi-view hull lines drawing of an $18^{\text {th }}$ century cargo ship kept at the Russian Navy Archives in St. Petersburg. Notes on the drawing suggest that the ship serving the Ottoman navy was captured by Russian forces and then documented through a detailed scaled drawing. The drawing can arguably be the oldest actual plan of a çekeleve or a sacoleva type ship of the period.
\end{abstract}

Keywords: Ottoman navy, sailing ships, history of shipbuilding, ship design, naval architecture, sacoleva.

\section{Öz}

Yelken çağında Osmanlı gemi tipleri tarihçiler tarafından iyi bilinmekle beraber, bu gemilerin teknik özellikleri hakkındaki kaynaklar Batı Avrupa'daki emsallerine göre oldukça sınırlıdır. Osmanlı arşivlerinde gemi kargolarıyla ilgili zengin envanter, liman ve diğer mali kayıtlar bulunurken, gemi endaze plan ya da krokileri gibi teknik kayıtlar yok denecek kadar azdır. Rus arşivlerinde yapılan güncel araştırmalar 18-19. yüzyıllara ait Osmanlı gemileriyle ilgili yeni kanıtları açığa çıkarmıştır. Bu çalışmada St. Petersburg Rus Bahriye Arşivlerinde bulunan, 18. yüzyıla ait bir kargo gemisinin endaze planı incelenmiştir. Plan üzerindeki notlar geminin Osmanlı donanmasına hizmet verirken Rus ordusu tarafından ele geçirildiğini ve daha sonra bu geminin ölçekli planının çıkarılması suretiyle kayıt altına alındığı bilgisini vermektedir. Söz konusu planının bu dönemde yaygın olarak kullanılan ve çekeleve ya da sacoleva olarak bilinen bir gemi tipine ait olduğu düşünülmektedir. Diğer taraftan, bu planın, bir çekeleveye ait olarak şu ana kadar tespit edilebilen en eski endaze planı olması mümkündür.

Anahtar sözcükler: Osmanlı donanması, yelkenli gemiler, gemi yapım teknolojisi tarihi, gemi tasarımı, gemi mimarlığı, çekeleve 


\section{Introduction}

Early examples of geometrical ship depictions in the Mediterranean date back to the $15^{\text {th }}$ century and are found in Venetian manuscripts such as Libro de Zorzi Trombetta da Modon ${ }^{1}$ and Fabrica di Galere. These early drawings can be seen as attempts to develop a pre-design concept and the standardization of hull structures. However, it has been argued that, for a long time, the craftsmanship played a dominant role in the building process rather than pre-planning. The use of multiview representations of ship hulls marks a ground breaking phase in the history of shipbuilding and manifested the beginning of modern naval architecture. Between the $16^{\text {th }}$ and the $19^{\text {th }}$ centuries, naval engineering gradually superseded the craftsmanship due to continuous efforts in applying the quantitative theory to ship design, especially in England and France. Innovative work by skilled naval constructors like Sir Anthony Deane ${ }^{2}$ (16381721), reference books such as Mathew Baker's Fragments of English Shipwrightery (1586), William Sutherland's The Shipbuilder's Assistant (1711), Pierre Bouguer's Traité du Navire (1746) and Duhamel du Monceau's Élémens de l'Architecture navale (1758) clearly indicate those efforts. War fleets began to be built according to designated plans; however, it was not until $19^{\text {th }}$ century that cargo or merchant ships introduced this technology. ${ }^{3}$

Contrary to Western Europe, the picture is ambiguous in the Eastern Mediterranean and the Black Sea with regard to naval architecture. Ottoman ships in the age of sail are well known by their types to the historians, but reliable sources on their technical characteristics are notably limited. Turkish archives are a rich repository of sources concerning Ottoman seafaring mostly and offer invaluable inventory accounts, harbor logs and fiscal records. However, besides miniature paintings, more informative visuals such as plans, sketches or any kind of scaled drawings are scarce. ${ }^{4}$ As the recent research reveals, the Russian State Archives have provided important technical evidence regarding $18^{\text {th }}$ and $19^{\text {th }}$ century Ottoman period ships. ${ }^{5}$ Among them is the drawing of a multi-view hull representation of an $18^{\text {th }}$ century Ottoman cargo ship kept in the Russian Navy Archives in St. Petersburg (Fig.1).

1 This manuscript is referred to as Timbotta by R. C. Anderson. See Roger Charles Anderson, "Italian Naval Architecture about 1445," Mariner's Mirror 11, 2 (1925): 135-163.

2 A. W. Jones, "Sir Anthony Deane," Mariner's Mirror 11, 2 (1925), 164-193.

3 David McGee, "From Craftsmanship to Draftsmanship: Naval Architecture and the Three Traditions of Early Modern Design," Technology and Culture 40, 2 (1999): 209-236.

Eric Rieth, "Mediterranean Ship Design in the Middle Ages," The Oxford Handbook of Maritime Archaeology, haz. Alexis Catsambis, Ben Ford, and Donny L. Hamilton (Oxford University Press, 2011) içinde, 406-425.

James Pritchard, "From Shipwright to Naval Constructor: The Professionalization of 18th-Century French Naval Shipbuilders," Technology and Culture 28,1 (1987): 1-25.

Richard Barker, "Whole-Moulding: A Preliminary Study of Early English and Other Sources," Shipbuilding Practice and Ship Design Methods from the Renaissance to the 18th century: A Workshop Report, haz. Horst Nowacki, Matteo Valleriani (Berlin: Max Planck Institute for the History of Science, 2003) içinde, 67-78.

4 Tuncay Zorlu, “Osmanlı Deniz Teknolojisi Üzerine,” Türkiye Araştırmaları Literatür Dergisi 4, 2 (2004): 297 353.

5 Emir Yener, “Osmanlı Denizcilik Tarihinde Rus Arşivlerinin Yeri,” Savaş Teknolojisi ve Deneysel Çalışmalar, haz. Kahraman Şakul (İstanbul: Tarih Vakfı Yurt Yayınları, 2013) içinde, 169-181.

Emir Yener, "Ottoman Seapower and Naval Technology during Catherine II's Turkish Wars 168-1792," International Naval Journal 9, 1 (2016): 4-14. 


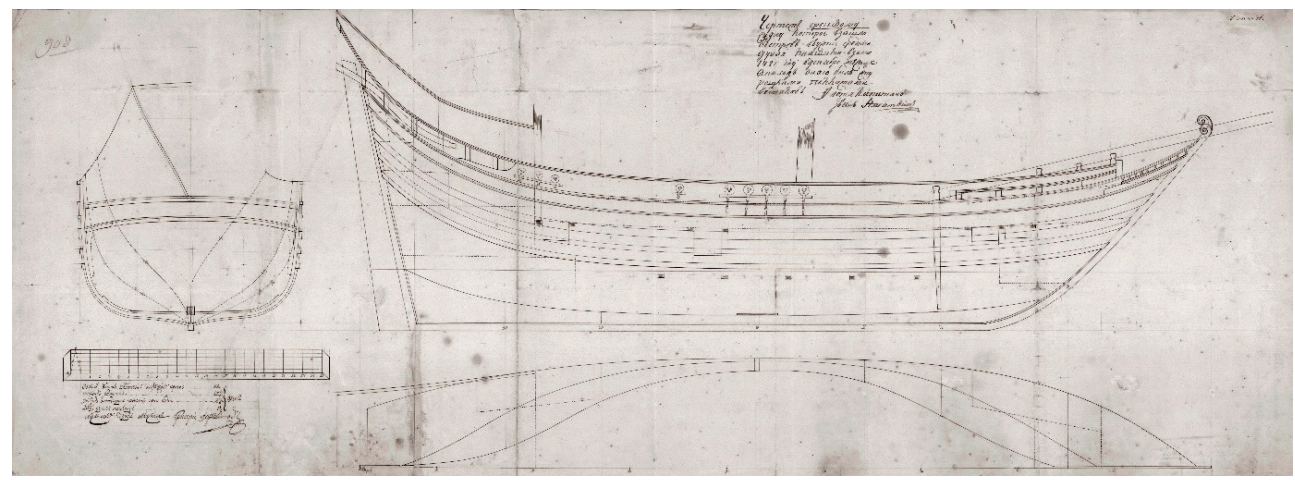

Fig. 1. Hull lines drawing of an Ottoman ship (Russian Navy Archives in St. Petersburg, Document No: f327op1d5213 (ф327оп1д5213) By courtesy of Emir Yener.

\section{The Drawing}

An Old Russian script on the upper part of the drawing made it possible to date the material and to find out the course of events that brought the ship into a Russian shipyard. Undersigned by captain Ivan Nagatkin, this note indicates that the Russian forces captured this ship on December 1772, in an island within the Danube Delta (Fig.1). The ship was referred to as being of Greek origin, carrying provisions for the Ottoman army. Nagatkin's note corresponds with the historical records that describe the $18^{\text {th }}$ century as a period of maritime warfare between Russia and the Ottoman Empire. After almost 300 years of monopoly, the Ottoman fleet completely lost its control over the Black Sea trade during the 1768-1774 wars against the Russian Navy. ${ }^{6}$ Consequently, it can be suggested that the captured ship would be one of the logistics carriers of the Ottoman fleet of the time. However, further evidence is not available to associate the ship with a specific event or a sea battle. The Greek origin of the ship can be explained by its Greek speaking crew, which might have been reported to Captain Nagatkin. The Greeks were known to be capable seamen heavily involved in shipping throughout the Ottoman period and also served in the Ottoman navy during war times. ${ }^{7}$ It is also possible that the captain or his soldiers were somehow familiar with this type of ship, which had been specifically built by Greek shipwrights during the period.

Shipbuilder Grigoriy Uvorçebenko signed the second script on the lower left part of the drawing, where he also added a scale (Fig. 1). He described the dimensions of the ship by using English feet. According to him, and when converted to metric, the ship had an overall length of 26,82 meters, while the width was 7,86 meters and the depth of the hold from the

6 İdris Bostan, Kürekli ve Yelkenli Osmanlı Gemileri (İstanbul: Bilge Yayınları, 2014), 147.

7 Halil İnalck, "Greeks in the Ottoman Economy and Finances, 1453-1500" Studies in Honor of Speros Vryonis, Jr. Volume II: Byzantinoslavica, Armeniaca, Islamica, the Balkans and Modern Greece, haz. Jelisaveta Stanojevich Allen, Christos P. Ioannides, John S. Langdon ve Stephen W. Reinert (New Rochelle / New York: Artistide D. Caratzas, 1993) içinde, 307-319. 
upper deck was 2,68 meters. Uvorçebenko was probably ordered to examine and record the enemy ship; even it was not a war vessel, as a part of systematic effort to develop know-how of the Russian shipbuilding industry. The competition and technology transfer in shipbuilding was frequent during the post-medieval period. The employment of foreign shipwrights in France, and that of the French shipbuilders in the Ottoman imperial shipyard Tersane- $i$ Amire in the $18^{\text {th }}$ century are only a few examples. ${ }^{8}$ A number of Ottoman ship drawings and reports in Russian naval archives, including the copies of original plans belonging to Ottoman Tersane-i Amire, confirm that the Russians were quite active in acquiring nautical intelligence. ${ }^{9}$

The drawing itself is not a simple sketch or line projections or a work of art, rather a scaled hull lines plan based on geometric principles, unsurprisingly different in some aspects in comparison with its modern counterparts (Fig.2). Similar to modern naval architecture standards, it delineates the ship in three views; sheer plan, body plan and a half breadth plan (Fig.1). Buttock lines are not visible, however, at least six stations including the midship bend are marked in each view with some additional stations in the half breadth plan. The sheer plan is quite pictorial and detailed rather than being entirely geometrical. The elevated stern is drawn together with the steering equipment consisting of a tiller and its shaft and a washboard over the deck. The prow has a bowsprit inclined at an acute angle and a stempost ending in the form of overlapped volute motifs. Wales and possible beam locations and two mast steps are also indicated in the sheer plan. The main mast, placed a little forward of midship station, is slightly raked forward while the thinner mizzenmast is set perpendicularly. Nine triple deadeyes are placed along the gunwale; five of them at amidships, a single one just next to this group towards stern and another three at the stern. The body plan or section plan on the left illustrates the cross sectional view of the ship both from aft (left) and forward (right) sides. According to the plan, the ship has a gentle wineglass shaped bottom profile at midships, smooth turn of the bilge and steep sides forming a relatively deep hull. The rabbets are also apparent on both chamfered sides of the keel. Wineglass shaped ship bottoms are well known in the Eastern Mediterranean and traced back from Classical Greek and Hellenistic to the Early Medieval periods by archaeological evidence. ${ }^{10}$ The lower part of the

8 Pritchard, "From Shipwright to Naval Constructor: 5.

Bostan, Kürekli ve Yelkenli Osmanlı Gemileri, 149-152.

Tuncay Zorlu ve Fatih Özbay, "Foreign Shipwrights under Selim III: The Case of Jacques Balthazard Le Brun," Seapower, Technology and Trade, haz. Dejanirah Couto, Feza Günergun ve Maria Pia Pedani (İstanbul: Denizler Kitabevi, 2014) içinde, 472-481.

9 Yener, "Osmanlı Denizcilik Tarihinde Rus Arşivlerinin Yeri," 174-176.

10 Adina Ben Zeev, Yaacov Kahanov, John Tresman ve Michal Artzy, The Ma'agan Mikhael Ship, Volume III: A Reconstruction of the Hull (Jerusalem: Israel Exploration Society, Leon Recanati Institute for Maritime Studies, University of Haifa, 2009), 22.

Patrice Pomey, Yaacov Kahanov ve Eric Rieth, "Transition from Shell to Skeleton in Ancient Mediterranean Ship-Construction: Analysis, Problems and Future Research," International Journal of Nautical Archaeology (IJNA) 41, 2 (2012): 235-314. 
drawing represents the half breadth plan consisting of at least two waterlines and the sheer line. Diagonals that are usually indicated in modern drawings are not present (Fig. 2).

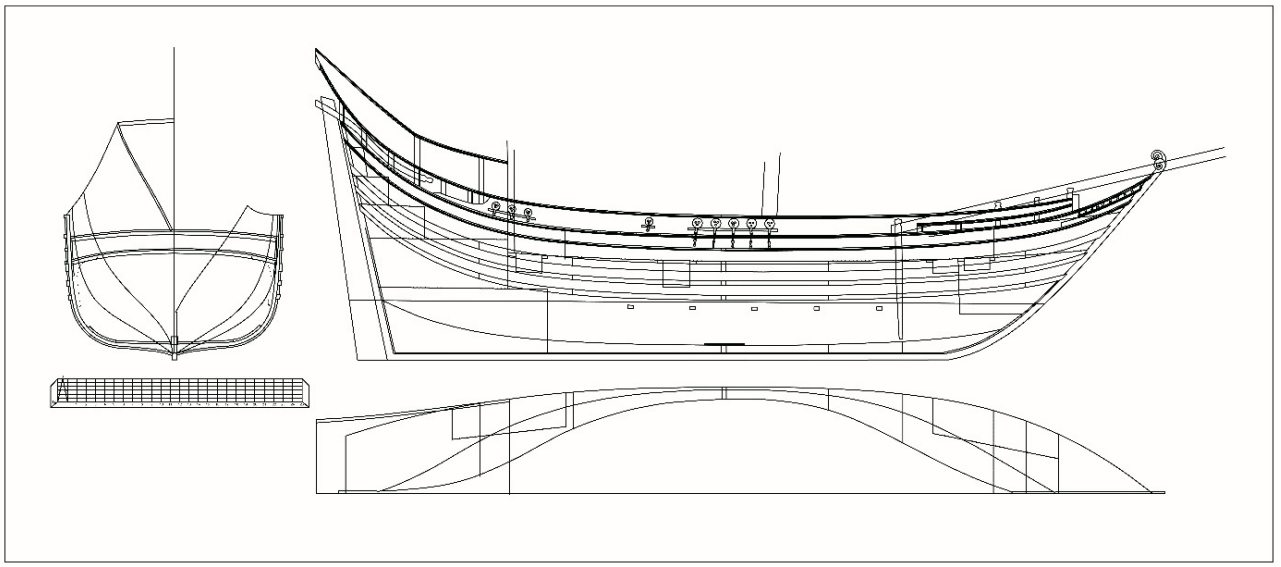

Fig. 2. Reproduction of the drawing (by Çisil Şanlıgençler)

Identifying the type of the vessel according to the historical information would be controversial. There is a variety of names referring to trading vessels such as brik, polaka, martiko, şebek, çamlıca, pergendi, çekeleve, pereme, tombaz and şayka. Nevertheless, the related records are not always descriptive. ${ }^{11}$ The absence of sails in the drawing makes the identification more difficult. However, other available parameters like hull shape and dimensions, masts and limited rigging evidence can provide a ground. Accordingly, among the aforementioned types, çekeleve would at least be argued to be associated with the drawing. Çekeleve was referred to as a two masted swift cargo ship about 17,5 - 23,5 meters long. It is recorded as early as the $16^{\text {th }}$ century, but mentioned often in Ottoman sources of the $18^{\text {th }}$ and early $19^{\text {th }}$ centuries. It served as the supplier of the charcoal and wood from Black Sea harbors to Istanbul and also served as the lighter of the navy. ${ }^{12}$ The etymologic origin of çekeleve dates back to the $12^{\text {th }}$ century Greek $\sigma \alpha \gamma o \lambda \alpha \iota \varphi \varepsilon \alpha$ (sagolaephea) or $\sigma \alpha \chi \chi 0 \lambda \eta \beta \alpha$ (sakhkholeba) characterizing a kind of spritsail. Too many variants of the term were adopted by other languages such as Arabic, šeqliwa or šāqlava, Italian saccoleva, French sacolevé or Turkish çekeleve, and probably derived from çekmek "to pull". ${ }^{13}$ Greek records of the $18^{\text {th }}$ and $19^{\text {th }}$ centuries report sacolevas sailing in the Aegean as well as in the Black Sea, and even to Malta, Genoa and Barcelona in the western Mediterranean. These records also indicate that the sacoleva could have carried up to three masts and its distinctive feature was a kind of

11 İdris Bostan, Beylikten İmparatorluğa Osmanlı Denizciliği (İstanbul: Kitap yayınevi, 2006), 249-339.

12 Bostan, Kürekli ve Yelkenli Osmanl Gemileri, 251.

Şenay Özdemir Gümüş, “Osmanlı Devleti’nin Karadeniz'de Ticaret Gemisi İnşa Politikası 1783-1824,” Sosyal Bilimler Enstitüsü Dergisi 9 (2012), 63-77.

13 Henry Kahane, Renée Kahane ve Andreas Tietze, The Lingua Franca in the Levant: Turkish Nautical Terms of Italian and Greek Origin (İstanbul: ABC Yayınevi, 1988), 563-564. 
spritsail. Its hull could be double ended with highly elevated ends or could have a transom stern. Available data also suggests approximately 26 tons of capacity and average crew size of 19 men for the sacoleva. ${ }^{14}$

The best pictorial evidence of the type belongs to a French painter Jean-Jerome Baugean (1764-1819) who was famous for the accuracy of his ship depictions (Fig.3). Baugean also noted that the sacoleva is a ship of Greek origin with a capacity no more than 100 tons that usually set sail in the seas of the Levant, and was also frequently seen along the coast of Italy. ${ }^{15} \mathrm{He}$ described the ship as having an elevated bow and stern, and emphasized that it was difficult to control the ship with her large sails. In his work, the mast heavily raked forward was carrying a mainsail, a topgallant sail, and a lower sail while the mizzenmast was rigged with a lateen sail, and another smaller lateen sail was placed on the very stern. Shrouds were also set with deadeyes.

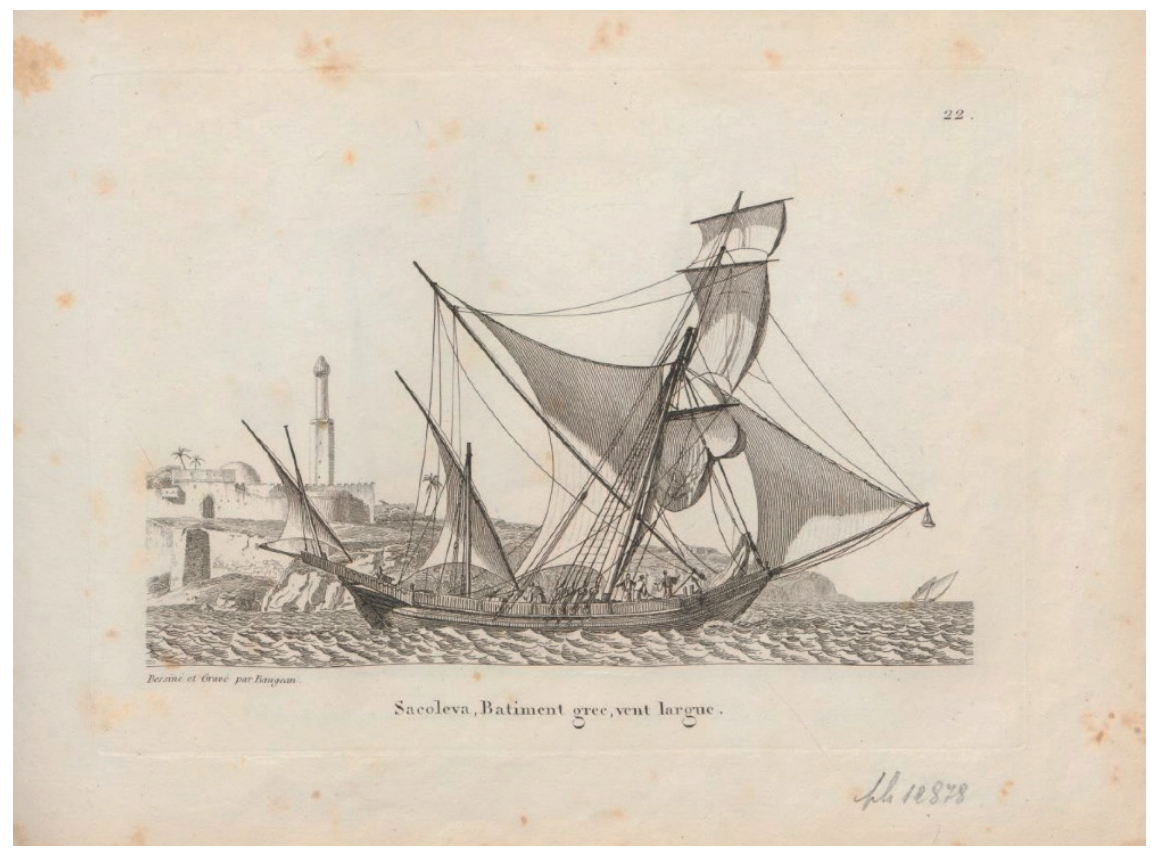

Fig. 3. Baugean's sacoleva depiction. ((Jean-Jérôme Baugean, Collection de toutes les Espèces de Bâtimens de Guerre et de Bâtimens Marchands qui naviguent sur l'Océan et dans la Méditerranée (Paris: L'Auteur / Bance aîné / Fantin, 1814), 8.

14 Apostolos Delis, "From Lateen to Square Rig: The Evolution of the Greek-owned Merchant Fleet and its Ships in the Eighteenth and Nineteenth centuries," The Mariners' Mirror 100, 1 (2014): 44-58.

15 Jean-Jérôme Baugean, Collection de toutes les Espèces de Bâtimens de Guerre et de Bâtimens marchands qui naviguent sur l'Océan et dans la Méditerranée (Paris: L'Auteur / Bance aîné / Fantin, 1814), 8. 
The hypothetical reconstruction of the rigging proposed in this study is largely based on Baugean's çekeleve depiction that is dated about a half century later than the Russian drawing (Fig. 4).

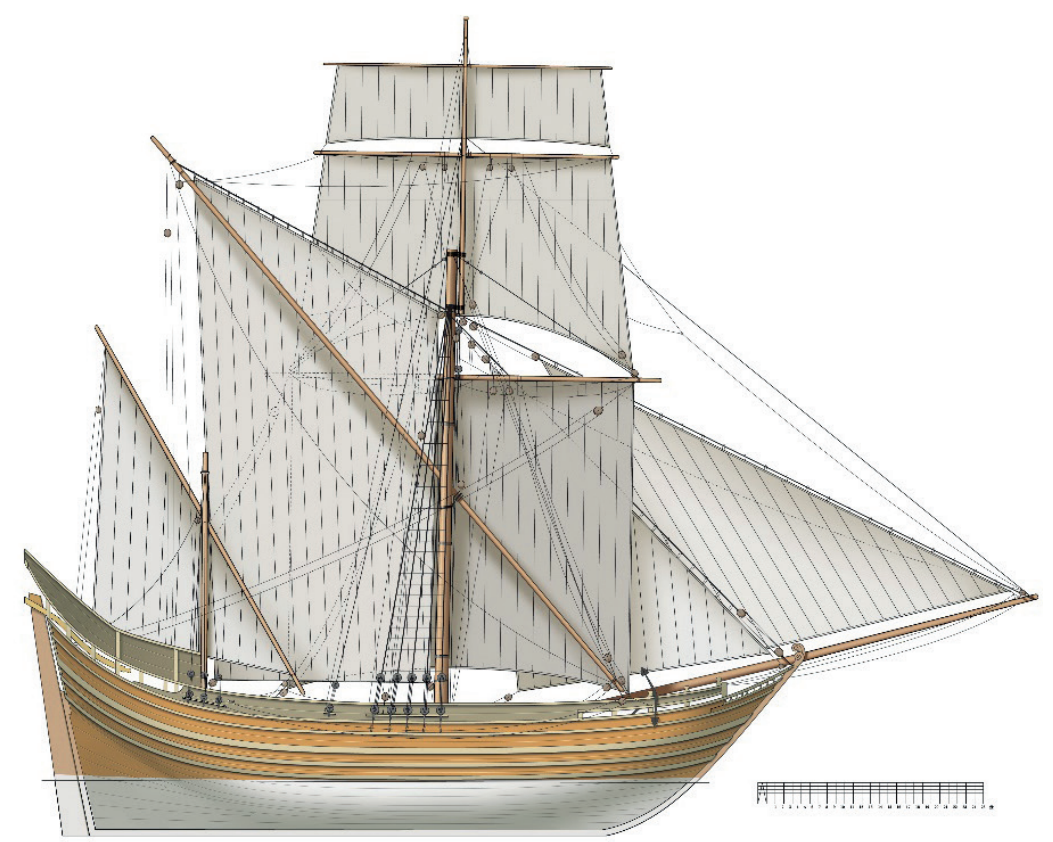

Fig. 4. Hypothetical illustration of the ship (by Laszlo Veres)

The only archaeological comparative example in the Black Sea is the Kitten shipwreck excavated off the Bulgarian coast between 2000 and 2003. Dated to late $18^{\text {th }}$ or early $19^{\text {th }}$ century, the ship was built with a later version of the traditional Mediterranean whole moulding technique. Batchvarov proposed that the Kitten ship was a single masted lateener, about 23 meters in length, with a beam of 7,56 meters. In addition to limited archaeological evidence of rigging, Batchvarov based his hypothetical reconstruction on the lateen rigged examples in the iconography, including çekeleve/sacoleva, but avoided to propose any specific historical type. ${ }^{16}$

16 Kroum Batchvarov, "The Kitten Shipwreck: The Archaeology and Reconstruction of a Black Sea Merchantman" (Doktora tezi, Texas A\&M Üniversitesi, 2009), 181-222; Kroum Batchvarov, "Shipwreck Reconstruction Based on the Archaeological Record: Mediterranean Whole-Molding and the Kitten Wreck Case Study," The Oxford Handbook of Maritime Archaeology, haz. Alexis Catsambis, Ben Ford, Donny L. Hamilton (Oxford University Press, 2011) içinde, 250-266. 
Although some historical references and construction characteristics might link this drawing to çekeleve or sakoleva type cargo carriers, it is unlikely to identify the type of the ship with certainty. Further archival evidence would improve the discussion. The meticulous documentation of the ship indicates a serious motivation to comprehend its structure. The Ottoman-Russian maritime struggle in the Black Sea was no doubt behind this motivation. As the archival sources and this study indicate, the Russian navy systematically examined the technology of Ottoman ships, including the modest sized cargo vessels, by utilizing the current principles of naval architecture of the period.

Peer-review: Externally peer-reviewed.

Conflict of Interest: The author has no conflict of interest to declare.

Grant Support: The author declared that this study has received no financial support.

Acknowledgements: I would like to thank Emir Yener for providing me with this rare drawing and kindly permitting its publication. I am also grateful to Professor Oleksandr Sereda (Istanbul University) for translating the notes written in Old Russian and appearing on the drawing. My special thanks go to Mr. Laszlo Veres for drawing the hypothetical illustration of the ship.

Hakem Değerlendirmesi: Dış bağımsız.

Çıkar Çatışması: Yazar çıkar çatışması bildirmemiştir.

Finansal Destek: Yazar bu çalışma için finansal destek almadığını beyan etmiş̧ir.

\section{BIBLIOGRAPHY / KAYNAKÇA}

\section{Archival Sources / Arşiv Kaynakları}

Russian Navy Archives, Saint Petersburg, f327op1d5213 (ф327оп1д5213)

\section{Printed Sources / Basılı Kaynaklar}

Anderson, Roger Charles. "Italian Naval Architecture about 1445." Mariner's Mirror 11, 2 (1925): 135-163.

Barker, Richard. "Whole-Moulding: A Preliminary Study of Early English and Other Sources." Shipbuilding Practice and Ship Design Methods from the Renaissance to the 18th century: A Workshop Report. Hazırlayan Horst Nowacki ve Matteo Valleriani içinde, 67-78. Berlin: Max Planck Institute for the History of Science, 2003.

Batchvarov, Kroum. "The Kitten Shipwreck: The Archaeology and Reconstruction of a Black Sea Merchantman.” Doktora tezi, Texas A\&M Üniversitesi, 2009.

Batchvarov, Kroum. "Shipwreck Reconstruction Based on the Archaeological Record: Mediterranean WholeMolding and the Kitten Wreck Case Study." The Oxford Handbook of Maritime Archaeology. Hazrllayan Alexis Catsambis, Ben Ford ve Donny L. Hamilton içinde 250-266. New York: Oxford University Press, 2011.

Baugean, Jean-Jérôme. Collection de toutes les Espèces de Bâtimens de Guerre et de Bâtimens Marchands qui naviguent sur l'Océan et dans la Méditerranée. Paris: L'Auteur / Bance aîné / Fantin, 1814.

Bostan, İdris. Beylikten İmparatorluğa Osmanlı Denizciliği. İstanbul: Kitap Yayınevi, 2006.

Bostan, İdris. Kürekli ve Yelkenli Osmanlı Gemileri. İstanbul: Bilge Yayınları, 2014. 
Delis, Apostolos. "From Lateen to Square Rig: The Evolution of the Greek-owned Merchant Fleet and its Ships in the Eighteenth and Nineteenth Centuries." The Mariners 'Mirror 100, 1 (2014): 44-58.

Johns, A. W. “Sir Anthony Deane.” The Mariner's Mirror 11,2 (1925): 164-193.

İnalc1k, Halil. "Greeks in the Ottoman Economy and Finances, 1453-1500." Studies in Honor of Speros Vryonis, Jr. Volume II: Byzantinoslavica, Armeniaca, Islamica, the Balkans and Modern Greece. Hazırlayan Jelisaveta Stanojevich Allen, Christos P. Ioannides, John S. Langdon ve Stephen W. Reinert içinde 307-319. New Rochelle / New York: Artistide D. Caratzas, 1993.

Kahane, Henry, Renée Kahane ve Andreas Tietze. Lingua Franca in the Levant: Turkish Nautical Terms of Italian and Greek Origin. İstanbul: ABC Yayınevi, 1988.

McGee, David. "From Craftsmanship to Draftsmanship: Naval Architecture and the Three Traditions of Early Modern Design.” Technology and Culture 40, 2 (1999): 209-236.

Özdemir Gümüş, Şenay. “Osmanlı Devleti’nin Karadeniz'de Ticaret Gemisi İnşa Politikası 1783-1824.” Sosyal Bilimler Enstitüsü Dergisi 9 (2012): 63-77.

Pomey, Patrice, Yaacov Kahanov ve Eric Rieth. "Transition from Shell to Skeleton in Ancient Mediterranean Ship-Construction: Analysis, Problems and Future Research." International Journal of Nautical Archaeology (IJNA) 41, 2 (2012): 235-314.

Pritchard, James. "From Shipwright to Naval Constructor: The Professionalization of 18th-Century French Naval Shipbuilders." Technology and Culture 28, 1 (1987): 1-25.

Rieth, Eric. "Mediterranean Ship Design in the Middle Ages." The Oxford Handbook of Maritime Archeology. Hazırlayan Alexis Catsambis, Ben Ford, ve Donny L. Hamilton içinde 406-425. New York: Oxford University Press, 2011.

Yener, Emir. “Osmanlı Denizcilik Tarihinde Rus Arşivlerinin Yeri.” Savaş Teknolojisi ve Deneysel Çalışmalar. Hazırlayan Kahraman Şakul içinde 169-181. İstanbul: Tarih Vakfı Yurt Yayınları, 2013.

Yener, Emir. "Ottoman Seapower and Naval Technology during Catherine II's Turkish Wars 168-1792." International Naval Journal 9, 1 (2016): 4-14.

Zeev, Adina Ben, Yaacov Kahanov, John Tresman ve Michal Artzy. The Ma'agan Mikhael Ship, Volume III: A Reconstruction of the Hull. Jerusalem: Israel Exploration Society, Leon Recanati Institute for Maritime Studies, University of Haifa, 2009.

Zorlu, Tuncay. “Osmanlı Deniz Teknolojisi Üzerine.” Türkiye Araştırmaları Literatür Dergisi 4, 2 (2004): 297-353.

Zorlu, Tuncay ve Fatih Özbay, "Foreign Shipwrights under Selim III: The Case of Jacques Balthazard Le Brun," Seapower, Technology and Trade. Hazırlayan Dejanirah Couto, Feza Günergun ve Maria Pia Pedani içinde 472-481. İstanbul: Denizler Kitabevi, 2014. 
